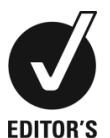

EDITOR'S

CHOICE

${ }^{1}$ St Marks Hospital, London, UK

${ }^{2}$ Barnet General Hospital, London, UK

${ }^{3}$ Department of

Gastroenterology, St Thomas Hospital, London, UK

\section{Correspondence to} Dr Mark A Samaan, markasamaan@gmail.com

Accepted 18 August 2016

\title{
A fluke diagnosis
}

\section{Charlie Toms, ${ }^{1}$ Samantha Mary-Anne Morgan, ${ }^{2}$ Mark A Samaan, ${ }^{3}$ Simon Anderson ${ }^{3}$}

\section{DESCRIPTION}

A 42-year-old man presented to the emergency department with a 1-week history of left iliac fossa pain, fever and diarrhoea. He reported no recent travel or unwell contacts. He originated in Sierra Leone but has lived in the UK for 15 years. His last visit to Sierra Leone was 5 years ago.

On examination, left iliac fossa tenderness was noted with suspicion of a palpable mass. He was febrile, tachycardic and normotensive. Blood tests revealed an elevated $C$ reactive protein of $120 \mathrm{mg} / \mathrm{L}$ and a white cell count of 15.7 (neutrophils $12.7) \times 10^{6} / \mathrm{mL}$. The remainder of his blood tests were within normal limits, and blood cultures grew no organisms. Chest and abdominal X-rays revealed no abnormalities.

CT imaging demonstrated inflammation of the proximal sigmoid colon with an adjacent collection (figure 1). Possible sigmoid diverticular changes were also reported leading to a working diagnosis of acute diverticulitis with a sealed localised perforation. ${ }^{1}$ Conservative treatment with intravenous antibiotics and analgesia resulted in a good clinical recovery and improvement of biochemical inflammatory markers. The patient was discharged, and an outpatient colonoscopy was planned.

Colonoscopy demonstrated a mild, patchy, resolving sigmoid colitis but no evidence of diverticular disease ${ }^{2}$ (figure 2). Sigmoid biopsy samples revealed a viable schistosome ovum with surrounding granuloma, eosinophils and Splendore-Hoeppli

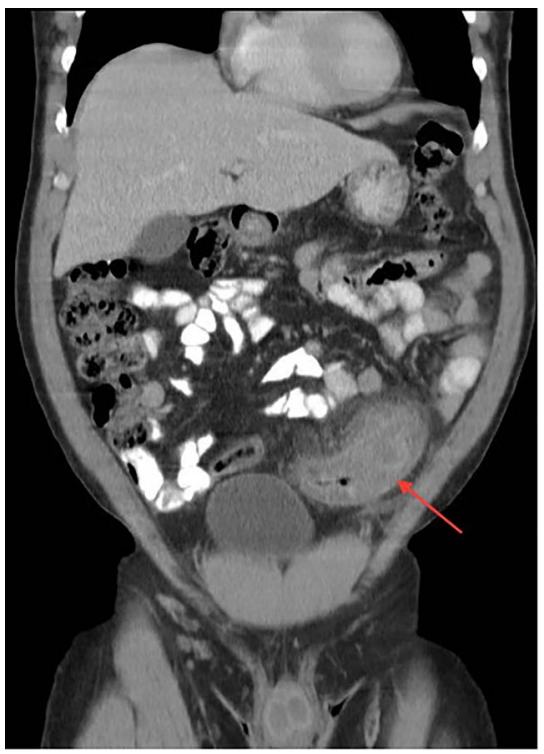

Figure $1 \mathrm{CT}$ images demonstrating inflammation of the proximal sigmoid colon with an adjacent collection (red arrow). phenomenon $^{3}$ (figure $3 \mathrm{~A}, \mathrm{~B}$ ). The ovum was subtyped as Schistosoma mansoni confirming the diagnosis of chronic schistosomal colitis with paracolic abscess formation.

Definitive treatment with a single, oral dose of praziquantel was administered. This is the treatment of choice for all species of schistosomiases and has a reported cure rate of $65-90 \%$.

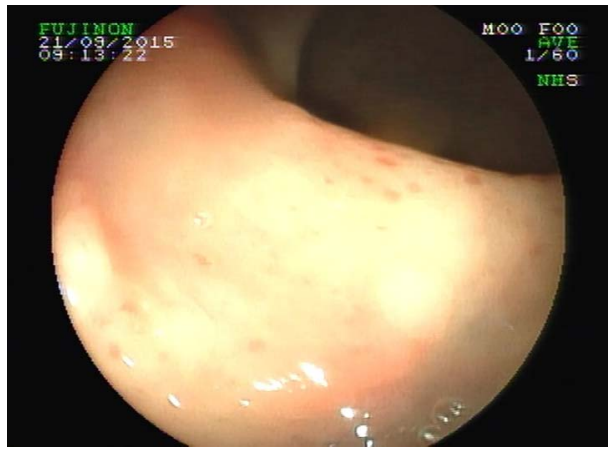

Figure 2 Endoscopic images showing a mild, patchy, resolving sigmoid colitis.

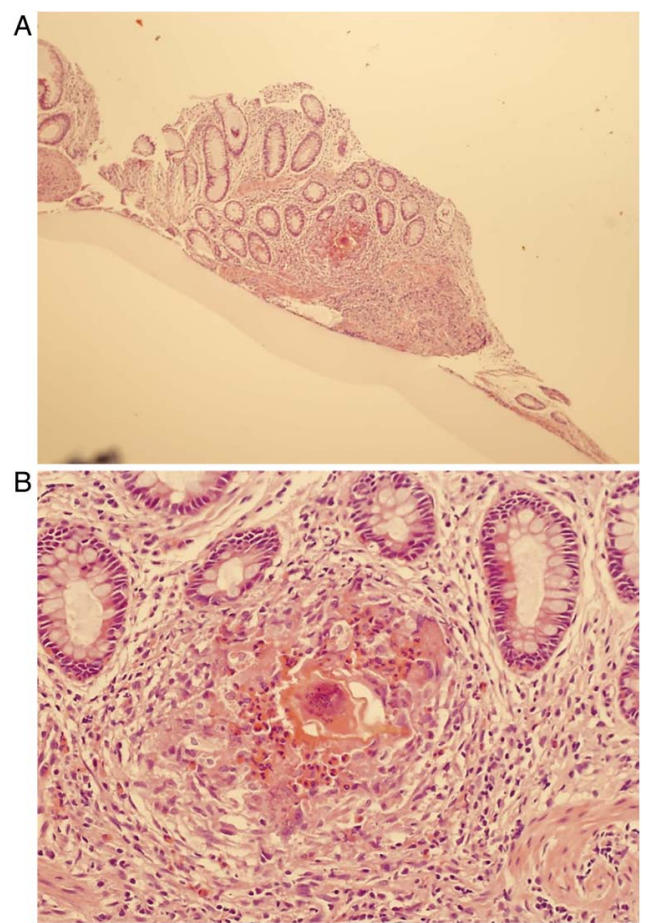

Figure 3 (A and B) Histology image of a sigmoid colon biopsy sample showing a viable schistosome ovum with surrounding granuloma, eosinophils and Splendore-Hoeppli phenomenon (deposition of amorphous, hyaline material around a pathogenic organism as a result of local antigen-antibody reaction). 


\section{Learning points}

- It is important to take a detailed travel history from any patient with diarrhoeal symptoms. This should include relevant travel and residence abroad, which may extend back to childhood.

- Schistosomiasis affects over 200 million people worldwide. It can lay dormant for many years and should be considered in patients from endemic areas, presenting with suggestive features.

- Schistosomal infection can cause colitis and paracolic, granulomatous collections (sometimes referred to as 'bilharzomas'). Colonic involvement is usually confined to the descending and sigmoid colon because the adult worms have a tendency to enter the inferior mesenteric vein.
Contributors $C T$, SM-AM, MAS and SA involved in gaining consent, collecting data, writing the case report and submitting.

Competing interests None declared.

Patient consent Obtained.

Provenance and peer review Not commissioned; externally peer reviewed.

\section{REFERENCES}

1 Thoeni RF, Cello JP. CT imaging of colitis. Radiology 2006;240:623-38.

2 Cao J, Liu WJ, Xu XY, et al. Endoscopic findings and clinicopathologic characteristics of colonic schistosomiasis: a report of 46 cases. World J Gastroenterol 2010;16:723-7.

3 Hussein MR. Mucocutaneous Splendore-Hoeppli phenomenon. J Cutan Pathol 2008;35:979-88.

Copyright 2016 BMJ Publishing Group. All rights reserved. For permission to reuse any of this content visit http://group.bmj.com/group/rights-licensing/permissions.

BMJ Case Report Fellows may re-use this article for personal use and teaching without any further permission.

Become a Fellow of BMJ Case Reports today and you can:

- Submit as many cases as you like

- Enjoy fast sympathetic peer review and rapid publication of accepted articles

- Access all the published articles

- Re-use any of the published material for personal use and teaching without further permission

For information on Institutional Fellowships contact consortiasales@bmjgroup.com

Visit casereports.bmj.com for more articles like this and to become a Fellow 